\title{
FORMULASI SHAMPO KRIM CAIR DARI KOMBINASI EKSTRAK DAUN WARU (Hibiscus tiliaceus L.) DAN SARI BUAH JERUK NIPIS (Citrus aurantifolia Swingle.)
}

\section{Mirawati}

Fakultas Farmasi Universitas Muslim Indonesia

\begin{abstract}
Leaves of hibiscus (Hibiscus tiliaceus L.) is widely used by communities to nourish the hair while the juice of lime (Citrus aurantifolia Swingle.) used to eliminate dandruff. Its use is directly less practical than if formulated in the form of shampoo. Cream shampoo formulation development using emulgator sodium lauryl sulfate and sodium hydroxide-coconut oil and the carbopol with concentration $0.1 \% \quad 0.3 \%$ and $0.5 \%$. This study aims to determine the formula that has the most optimal stability. The evaluation was done by testing the stability of organoleptis, homogeneity, determination of $\mathrm{pH}$, type of emulsion, creaming volume, viscosity and size of the dispersed drops before and after accelerated storage. The results show the entire formula is stable because it does not experience phase separation, but the formula that stability is the most optimal use of sodium lauryl sulfate emulgator and karbopol with a concentration of $0.1 \%$ because it has a different viscosity and yield value are not significant $(\alpha=0.5)$.
\end{abstract}

Keywords: Leaf Hibiscus, Lemon, Cream Shampoo, Stability

\section{PENDAHULUAN}

Waru dengan nama ilmiah Hibiscus tiliaceus $\mathrm{L}$ dikenal sebagai tanaman yang kaya akan manfaat. Daunnya yang lebar memiliki banyak khasiat, diantaranya untuk menyuburkan dan mengurangi kerontokan pada rambut. Daun waru mengandung senyawa saponin, flavanoid dan juga polifenol (Dalimartha, 2000). Penelitan Asep Gana tentang efek ekstrak daun waru, minyak wijen dan daun mangkok terhadap kelebatan rambut pada tikus wistar, dimana hasilnya menunjukan bahwa ekstrak etanol daun waru sebanyak 2,5 \% meningkatkan pertumbuhan rambut pada tikus wistar sebesar 6,40 \% (Gana, 2007).

Buah jeruk nipis memiliki khasiat diantaranya dapat menyuburkan rambut, menghilangkan ketombe dan mengurangi kerontokan pada rambut. Jeruk nipis mengandung minyak atsiri limonene dan linalool. Selain itu, juga mengandung flavanoid, seperti poncirin, hesperidine, rhoifolin dan naringin, asam sitrat. Dalam $100 \mathrm{~g}$ 
Formulasi Shampo Krim Cair Dari Kombinasi Ekstrak Daun Waru (Dan Sari Buah Jeruk Nipis

jeruk nipis mengandung vitamin C 27 $\mathrm{mg}$, vitamin $B_{1} 0,04 \mathrm{mg}$, zat besi 0,6 $\mathrm{mg}$, lemak $0,1 \mathrm{~g}$, kalori $37 \mathrm{~g}$, protein $0,8 \mathrm{~g}$ dan air $86 \mathrm{gr}$. Kandungan vitamin pada jeruk nipis berkhasiat menyuburkan dan mengurangi kerontokan pada rambut (Hariana, 2004).

Konsentrasi buah jeruk nipis yang digunakan untuk menghilangkan minyak pada kulit kepala sebesar $1 \%$ (Ernest, 1999).

Berdasarkan dari kegunaan jeruk nipis dan daun waru maka peneliti mencoba memformulasi shampo krim cair dengan mengkombinasikan kedua tanaman tersebut agar diperoleh bentuk sediaan yang kestabilannya optimal dan penggunaanya menjadi lebih praktis. Untuk memperoleh sediaan dengan kestabilan optimum maka perlu memperhatikan dua faktor penting yaitu yaitu kekentalan (viskositas) dan penggunaan bahan penstabil emulsi (emulgator).

\section{METODE PENELITIAN}

Alat dan Bahan, Alat dan bahan yang akan digunakan disiapkan sesuai dengan kebutuhan penelitian.

\section{Prosedur Penelitian}

\section{A. Penyiapan ekstrak daun waru dan sari buah jeruk nipis}

\section{Pembuatan}

a) Ekstrak daun waru

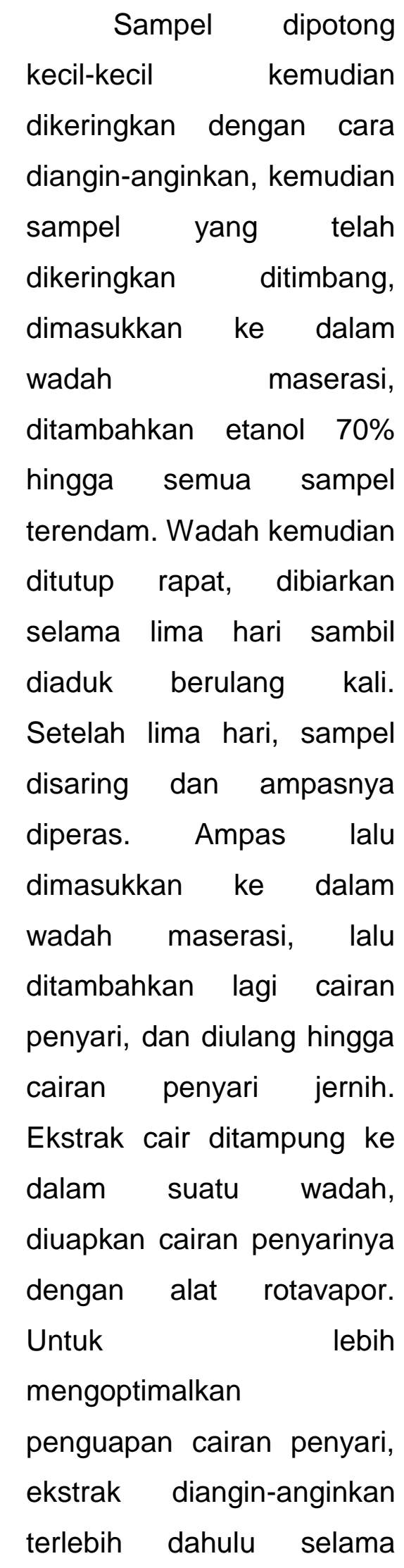


Formulasi Shampo Krim Cair Dari Kombinasi Ekstrak Daun Waru (Dan Sari Buah Jeruk Nipis

beberapa hari hingga diperoleh ekstrak kental.

b) Sari buah jeruk nipis

Sampel dibersihkan dari kotoran-kotoran yang melekat, kemudian di potong menjadi 4 bagian, masing-masing bagian dijuicer untuk diambil sari buahnya, kemudian ditampung dalam sebuah wadah.

\section{Karakteristik}

Adapun karakteristik ekstrak daun waru dan sari buah jeruk nipis yang akan diamati meliputi organoleptis dan $\mathrm{pH}$ untuk sari jeruk nipis

\section{B. Pembuatan sediaan shampo}

\section{krim cair}

Disiapkan alat dan bahan. Ditimbang semua bahan yang akan digunakan sesuai dengan perhitungan. Dipisahkan fase minyak dan fase air. Fase minyak dibuat dengan cara melebur setil alkohol, lanolin, minyak kelapa dan propil paraben hingga suhu $70^{\circ} \mathrm{C}$. Fase air dibuat dengan cara mendispersikan karbopol dengan 3 tetes $\mathrm{NaOH}$ encer kemudian ditambahkan $10 \mathrm{ml}$ air suling, setelah dispersi sempurna, ditambahkan natrium lauril sulfat, gliserin, metil paraben dan EDTA yang sebelumnya telah dilarutkan dalam $15 \mathrm{ml}$ air suling lalu dipanaskan hingga suhu $70^{\circ} \mathrm{C}$, diaduk hingga homogen. Kemudian fase minyak dituang ke dalam fase air sedikit demi sedikit lalu dimixer dengan pengocokan berselang (dimixer selama 1 menit istirahat 20 detik). Lalu ditambahkan ekstrak daun waru (Hibiscus tiliaceus L.) dan sari buah jeruk nipis (Citrus aurantifolia Swingle), alfa tokoferol, sisa air suling dan pengaroma, diaduk hingga homogen. Formula dengan variasi emulgator dan peningkat viskositas lain dibuat dengan cara yang sama.

\section{Evaluasi sediaan}

Evaluasi sediaan dilakukan dengan menentukan beberapa parameter yaitu homogenitas, organoleptis, penentuan tipe emulsi, pengukuran $\mathrm{pH}$, pengukuran viskositas dan tipe aliran, pengamatan tetes terdispersi.

\section{a. Homogenitas}

Pengujian homogenitas ini dilakukan dengan cara meletakkan sedikit krim diantara 2 kaca objek dan diperhatikan adanya partikel partikel kasar 
Formulasi Shampo Krim Cair Dari Kombinasi Ekstrak Daun Waru (Dan Sari Buah Jeruk Nipis

atau ketidakhomogenan secara visual.

b. Organoleptis

Organoleptis meliputi warna, konsistensi dan bau sediaan shampo krim cair.

c. Penentuan Tipe emulsi

Penentuan tipe emulsi dengan menggunakan metode hantaran listrik yaitu sampel emulsi yang dibuat dimasukan $25 \mathrm{ml}$ kedalam wadah kemudian diuji daya hantarnya dengan multitester. Apabila jarum multitester bergerak maka tipe emulsi M/A dan demikian sebaliknya.

d. Pengukuran pH

Pengukuran menggunakan $\mathrm{pH}$ meter. Range toleransi $\mathrm{pH}$ shampo berkisar antara $5.0-7.0$.

e. Pengukuran Viskositas dan penentuan tipe aliran

Pengukuran viskositas sediaan shampo krim cair. Pengukuran dilakukan dengan menggunakan Viskometer Brookfield spindle nomor 64 dengan tiga kali replikasi. Kemudian dilanjutkan dengan penentuan tipe aliran dari sediaan. f. Pengamatan Tetes terdispersi

Pengamatan dilakukan dengan meneteskan emulsi pada objek gelas, kemudian ditutup dengan dek gelas. Setelah itu diamati dengan menggunakan mikroskop dengan perbesaran $\quad 40 \times 10$.

\section{Pengujian Kestabilan Sediaan}

Untuk mengetahui kestabilan sediaan selama penyimpanan dilakukan uji pemisahan fase yang terdiri dari volume kriming dan metode sentrifugasi. Sedangkan untuk mengetahui formula yang memiliki kestabilan optimal selama penyimpanan dilakukan penyimpanan dipercepat dengan kondisi dipaksakan yaitu Freeze thaw pada suhu antara $5^{\circ} \mathrm{C}$ dan $35^{\circ} \mathrm{C}$ masing-masing 12 jam selama 10 siklus. Kemudian dilakukan kembali evaluasi sediaan dan dibandingkan antara hasil yang diperoleh sebelum dan setelah penyimpanan dipercepat.

\section{a. Volume kriming}

Pada pengujian volume kriming dilakukan dengan cara shampo krim cair diambil $20 \mathrm{ml}$ ditempatkan dalam gelas ukur dan ditutup kemudian disimpan pada kondisi dipaksakan. Kemudian diamati volume 
Formulasi Shampo Krim Cair Dari Kombinasi Ekstrak Daun Waru (Dan Sari Buah Jeruk Nipis

kriming yang terbentuk setiap satu siklus hingga siklus ke 10.

b. Sentrifuge

Pengujian ini dilakukan dengan cara sampel diambil sebanyak $10 \mathrm{ml}$ kemudian dimasukan kedalam tabung sentrifuge lalu disentrifuge dengan kecepatan 2500 rpm dalam waktu 15 menit. Setelah itu alat sentrifugasi dimatikan, emulsi diamati dan dicatat pemisahannya.

\section{HASIL PENELITIAN}

Evaluasi kestabilan formula shampo krim cair dari kombinasi ekstrak daun waru (Hibiscus tiliaceus L.) dan sari buah jeruk nipis (Citrus aurantifolia Swingle.) berdasarkan variasi emulgator dan variasi konsentrasi bahan peningkat viskositas (pengental) memberikan hasil sebagai berikut :

Tabel 1. Hasil Pengamatan Organoleptis Ekstrak Sampel

\begin{tabular}{cccc}
\hline No. & Ekstrak/Sari & Jenis Pemeriksaan & Hasil \\
\hline & & Bau & Khas \\
1. & Daun Waru (Hibiscus tiliaceus L.) & Warna & Hijau kehitaman \\
& & Konsistensi & Kental \\
\hline & & Bau & Khas \\
2. & Sari buah Jeruk Nipis (Citrus & Warna & Kuning pucat \\
& Aurantifolia Swingle.) & Konsistensi & Cair \\
& & $\mathrm{pH}$ & 3 \\
\hline
\end{tabular}

Tabel 2. Hasil Pengamatan Organoleptis Shampo krim Cair Sebelum dan Sesudah Penyimpanan Dipercepat

\begin{tabular}{|c|c|c|c|c|c|}
\hline \multirow{2}{*}{ No } & \multirow{2}{*}{ Sediaan } & \multirow{2}{*}{ Formula } & \multirow{2}{*}{ Pemeriksaan } & \multicolumn{2}{|c|}{ Kondisi } \\
\hline & & & & Sebelum & Sesudah \\
\hline \multirow{3}{*}{1.} & \multirow{3}{*}{$\begin{array}{l}\text { Emulgator } \mathrm{NaOH}-\text { Minyak kelapa } \\
\text { (A1) }\end{array}$} & B1 & $\begin{array}{c}\text { Bau } \\
\text { Warna } \\
\text { Konsistensi }\end{array}$ & $\begin{array}{c}\text { Harum } \\
\text { Hijau pucat } \\
\text { Kental }\end{array}$ & $\begin{array}{c}\text { Harum } \\
\text { Hijau pucat } \\
\text { Kental }\end{array}$ \\
\hline & & B2 & $\begin{array}{c}\text { Bau } \\
\text { Warna } \\
\text { Konsistensi }\end{array}$ & $\begin{array}{c}\text { Harum } \\
\text { Hijau pucat } \\
\text { Kental }\end{array}$ & $\begin{array}{c}\text { Harum } \\
\text { Hijau pucat } \\
\text { Kental }\end{array}$ \\
\hline & & B3 & $\begin{array}{c}\text { Bau } \\
\text { Warna } \\
\text { Konsistensi }\end{array}$ & $\begin{array}{c}\text { Harum } \\
\text { Hijau pucat } \\
\text { Kental }\end{array}$ & $\begin{array}{c}\text { Harum } \\
\text { Hijau pucat } \\
\text { Kental }\end{array}$ \\
\hline \multirow{3}{*}{2.} & \multirow{3}{*}{$\begin{array}{l}\text { Emulgator Natrium Lauril Sulfat } \\
\text { (A2) }\end{array}$} & B1 & $\begin{array}{c}\text { Bau } \\
\text { Warna } \\
\text { Konsistensi }\end{array}$ & $\begin{array}{c}\text { Harum } \\
\text { Hijau pucat } \\
\text { Kental }\end{array}$ & $\begin{array}{c}\text { Harum } \\
\text { Hijau pucat } \\
\text { Kental }\end{array}$ \\
\hline & & B2 & $\begin{array}{c}\text { Bau } \\
\text { Warna } \\
\text { Konsistensi }\end{array}$ & $\begin{array}{c}\text { Harum } \\
\text { Hijau pucat } \\
\text { Kental }\end{array}$ & $\begin{array}{c}\text { Harum } \\
\text { Hijau pucat } \\
\text { Kental }\end{array}$ \\
\hline & & B3 & $\begin{array}{c}\text { Bau } \\
\text { Warna } \\
\text { Konsistensi }\end{array}$ & $\begin{array}{c}\text { Harum } \\
\text { Hijau pucat } \\
\text { Kental }\end{array}$ & $\begin{array}{c}\text { Harum } \\
\text { Hijau pucat } \\
\text { Kental }\end{array}$ \\
\hline
\end{tabular}


Formulasi Shampo Krim Cair Dari Kombinasi Ekstrak Daun Waru (Dan Sari Buah Jeruk Nipis

\begin{tabular}{ccccc}
\hline & B1 & $\begin{array}{c}\text { Bau } \\
\text { Warna } \\
\text { Konsistensi }\end{array}$ & $\begin{array}{c}\text { Harum } \\
\text { Hijau pucat } \\
\text { Kental }\end{array}$ & $\begin{array}{c}\text { Harum } \\
\text { Hijau pucat } \\
\text { Kental }\end{array}$ \\
\cline { 2 - 5 } 3. $\begin{array}{c}\text { Kombinasi emulgator NaOH- } \\
\text { Minyak kelapa dan Natrium lauril } \\
\text { sulfat (A3) }\end{array}$ & B2 & $\begin{array}{c}\text { Bau } \\
\text { Warna } \\
\text { Konsistensi }\end{array}$ & $\begin{array}{c}\text { Harum } \\
\text { Hijau pucat } \\
\text { Kental }\end{array}$ & $\begin{array}{c}\text { Harum } \\
\text { Hijau pucat } \\
\text { Kental }\end{array}$ \\
\cline { 2 - 5 } & B3 & $\begin{array}{c}\text { Bau } \\
\text { Warna } \\
\text { Konsistensi }\end{array}$ & $\begin{array}{c}\text { Harum } \\
\text { Hijau pucat } \\
\text { Kental }\end{array}$ & $\begin{array}{c}\text { Harum } \\
\text { Hijau pucat } \\
\text { Kental }\end{array}$ \\
\hline
\end{tabular}

Keterangan :

A1 : Formula dengan emulgator $\mathrm{NaOH}-$ Minyak Kelapa

A2 : Formula dengan emulgator Natrium lauril sulfat

A3 : Formula dengan kombinasi emulgator $\mathrm{NaOH}$-Minyak kelapa dan Natrium lauril sulfat

B1 : Formula dengan konsentrasi $0,1 \%$ bahan peningkat viskositas

B2 : Formula dengan konsentrasi $0,3 \%$ bahan peningkat viskositas

B3 : Formula dengan konsentrasi $0,5 \%$ bahan peningkat viskositas

Tabel 3. Hasil Pengukuran pH Shampo Krim Cair Sebelum dan Sesudah Penyimpanan Dipercepat

\begin{tabular}{ccccc}
\hline \multirow{2}{*}{ No. } & \multirow{2}{*}{ Sediaan } & \multirow{2}{*}{ Formula } & \multicolumn{2}{c}{ Nilai pH } \\
\cline { 4 - 5 } & \multirow{2}{*}{ Emulgator NaOH-Minyak kelapa (A1) } & Sebelum & Sesudah \\
\cline { 3 - 5 } & & B2 & 5,0 & 5,0 \\
& B3 & 5,0 & 5,0 \\
\hline \multirow{2}{*}{ 2. } & \multirow{2}{*}{ Emulgator Natirum lauril sulfat (A1) } & B1 & 5,0 & 5,0 \\
& & B2 & 5,0 & 5,0 \\
& & B3 & 5,0 & 5,0 \\
\multirow{2}{*}{ 3. } & \multirow{2}{*}{ Kombinasi emulgator NaOH-Minyak } & B1 & 5,1 & 5,1 \\
& kelapa dan Natrium Lauril Sulfat (A2) & B2 & 5,0 & 5,0 \\
& & B3 & 5,1 & 5,1 \\
\hline
\end{tabular}

Tabel 4. Hasil Pengamatan Homogenitas Shampo krim Cair Sebelum dan Sesudah Penyimpanan Dipercepat

\begin{tabular}{|c|c|c|c|c|}
\hline \multirow{2}{*}{ No. } & \multirow{2}{*}{ Sediaan } & \multirow{2}{*}{ Formula } & \multicolumn{2}{|c|}{ Kondisi sediaan } \\
\hline & & & Sebelum & Sesudah \\
\hline \multirow{3}{*}{1.} & \multirow{3}{*}{ Emulgator $\mathrm{NaOH}$-Minyak kelapa (A1) } & B1 & Homogen & Homogen \\
\hline & & B2 & Homogen & Homogen \\
\hline & & B3 & Homogen & Homogen \\
\hline \multirow{3}{*}{2.} & \multirow{3}{*}{ Emulgator Natirum lauril sulfat (A2) } & & Homo & Homogen \\
\hline & & B2 & Homogen & Homogen \\
\hline & & B3 & Homogen & Homogen \\
\hline \multirow{3}{*}{3.} & \multirow{3}{*}{$\begin{array}{l}\text { Kombinasi emulgator } \mathrm{NaOH} \text {-Minyak } \\
\text { kelapa dan Natrium Lauril Sulfat (A3) }\end{array}$} & B1 & Homogen & Homogen \\
\hline & & B2 & Homogen & Homogen \\
\hline & & B3 & Homogen & Homogen \\
\hline
\end{tabular}


Formulasi Shampo Krim Cair Dari Kombinasi Ekstrak Daun Waru (Dan Sari Buah Jeruk Nipis

Tabel 5. Hasil Penentuan Tipe emulsi Dengan Metode Hantaran Listrik Sebelum dan Sesudah Penyimpanan Dipercepat

\begin{tabular}{|c|c|c|c|c|}
\hline \multirow{2}{*}{ No. } & \multirow{2}{*}{ Sediaan } & \multirow{2}{*}{ Formula } & \multicolumn{2}{|c|}{ Tipe emulsi } \\
\hline & & & Sebelum & Sesudah \\
\hline \multirow{3}{*}{1.} & \multirow{3}{*}{ Emulgator $\mathrm{NaOH}-$ Minyak kelapa (A1) } & B1 & $\mathrm{m} / \mathrm{a}$ & $\mathrm{m} / \mathrm{a}$ \\
\hline & & B2 & $\mathrm{m} / \mathrm{a}$ & $\mathrm{m} / \mathrm{a}$ \\
\hline & & B3 & $\mathrm{m} / \mathrm{a}$ & $\mathrm{m} / \mathrm{a}$ \\
\hline \multirow{3}{*}{2.} & \multirow{3}{*}{ Emulgator Natirum lauril sulfat (A2) } & B1 & $\mathrm{m} / \mathrm{a}$ & $\mathrm{m} / \mathrm{a}$ \\
\hline & & B2 & $\mathrm{m} / \mathrm{a}$ & $\mathrm{m} / \mathrm{a}$ \\
\hline & & B3 & $\mathrm{m} / \mathrm{a}$ & $\mathrm{m} / \mathrm{a}$ \\
\hline \multirow{3}{*}{3.} & \multirow{3}{*}{$\begin{array}{l}\text { Kombinasi emulgator NaOH-Minyak } \\
\text { kelapa dan Natrium Lauril Sulfat (A3) }\end{array}$} & B1 & $\mathrm{m} / \mathrm{a}$ & $\mathrm{m} / \mathrm{a}$ \\
\hline & & $\mathrm{B} 2$ & $\mathrm{~m} / \mathrm{a}$ & $\mathrm{m} / \mathrm{a}$ \\
\hline & & B3 & $\mathrm{m} / \mathrm{a}$ & $\mathrm{m} / \mathrm{a}$ \\
\hline
\end{tabular}

Tabel 6. Hasil Pengukuran Volume Kriming Shampo Krim Cair Ekstrak Daun Waru (Hibiscus tiliaceus L) dan Sari Buah Jeruk Nipis (Citrus aurantifolia Swingle.)

\begin{tabular}{cccccccccccc}
\hline \multirow{2}{*}{ Sediaan } & \multirow{10}{*}{ Formula } & \multicolumn{10}{c}{ Siklus ke- } \\
\cline { 3 - 11 } & & $\mathbf{1}$ & $\mathbf{2}$ & $\mathbf{3}$ & $\mathbf{4}$ & $\mathbf{5}$ & $\mathbf{6}$ & $\mathbf{7}$ & $\mathbf{8}$ & $\mathbf{9}$ & $\mathbf{1 0}$ \\
\hline \multirow{3}{*}{ Emulgator NaOH-Minyak kelapa } & Formula B1 & 0 & 0 & 0 & 0 & 0 & 0 & 0 & 0 & 0 & 0 \\
& Formula B2 & 0 & 0 & 0 & 0 & 0 & 0 & 0 & 0 & 0 & 0 \\
& Formula B3 & 0 & 0 & 0 & 0 & 0 & 0 & 0 & 0 & 0 & 0 \\
\hline \multirow{3}{*}{ Emulgator Natirum lauril sulfat } & Formula B1 & 0 & 0 & 0 & 0 & 0 & 0 & 0 & 0 & 0 & 0 \\
& Formula B2 & 0 & 0 & 0 & 0 & 0 & 0 & 0 & 0 & 0 & 0 \\
& Formula B3 & 0 & 0 & 0 & 0 & 0 & 0 & 0 & 0 & 0 & 0 \\
\hline Kombinasi emulgator NaOH- & Formula B1 & 0 & 0 & 0 & 0 & 0 & 0 & 0 & 0 & 0 & 0 \\
Minyak kelapa dan Natrium Lauril & Formula B2 & 0 & 0 & 0 & 0 & 0 & 0 & 0 & 0 & 0 & 0 \\
Sulfat & Formula B3 & 0 & 0 & 0 & 0 & 0 & 0 & 0 & 0 & 0 & 0 \\
\hline
\end{tabular}

Tabel 7. Hasil Pengujian Sentrifugasi Sediaan Shampo Krim Cair Sebelum dan Sesudah Penyimpanan Dipercepat

\begin{tabular}{|c|c|c|c|c|}
\hline \multirow{2}{*}{ No. } & \multirow{2}{*}{ Sediaan } & \multirow{2}{*}{ Formula } & \multicolumn{2}{|c|}{ Kondisi } \\
\hline & & & Sebelum & Sesudah \\
\hline \multirow{3}{*}{1.} & \multirow{3}{*}{$\begin{array}{c}\text { Emulgator } \mathrm{NaOH}-M i n y a k \\
\text { kelapa (A1) }\end{array}$} & B1 & $\neq$ & $\neq$ \\
\hline & & B2 & $\neq$ & $\neq$ \\
\hline & & B3 & $\neq$ & $\neq$ \\
\hline \multirow{3}{*}{2.} & \multirow{3}{*}{$\begin{array}{l}\text { Emulgator Natirum lauril } \\
\text { sulfat(A2) }\end{array}$} & B1 & $\neq$ & $\neq$ \\
\hline & & B2 & $\neq$ & $\neq$ \\
\hline & & B3 & $\neq$ & $\neq$ \\
\hline \multirow{3}{*}{3.} & Kombinasi emulgator & B1 & $\neq$ & $\neq$ \\
\hline & $\mathrm{NaOH}-$ Minyak kelapa dan & B2 & $\neq$ & $\neq$ \\
\hline & Natrium Lauril Sulfat(A3) & B3 & $\neq$ & $\neq$ \\
\hline
\end{tabular}

\section{PEMBAHASAN}

Setelah pembuatan sediaan, dilakukan pengujian kestabilan berdasarkan sembilan parameter pada kondisi sebelum dan sesudah penyimpanan dipercepat, diantaranya pemeriksaan organoleptis, pengujian homogenitas, pengujian tipe emulsi, pengukuran $\mathrm{pH}, \quad$ pengukuran viskositas, penentuan nilai yield, 
Formulasi Shampo Krim Cair Dari Kombinasi Ekstrak Daun Waru (Dan Sari Buah Jeruk Nipis

pengujian volume kriming, pengujian pemisahan fase dengan metode sentrifugasi dan penentuan tetes terdispersi. Penyimpanan dipercepat dilakukan menggunakan metode siklus suhu yaitu pada suhu $5^{\circ} \mathrm{C}$ dan $35^{\circ} \mathrm{C}$ selama 10 siklus, masing-masing siklus berdurasi 12 jam. Tujuan dilakukannya penyimpanan dipercepat adalah untuk mempercepat proses peruraian dari bahan-bahan dan untuk mempersingkat waktu pengujian.

Pada penelitian ini, peneliti memvariasikan emulgator dan konsentrasi bahan peningkat viskositas. Emulgator yang digunakan pada tiap-tiap formula yakni emulgator $\mathrm{NaOH}-M i n y a k$ kelapa (sabun alkali), Natrium lauril sulfat (detergen) dan kombinasi $\mathrm{NaOH}-M i n y a k$ kelapa dan Natrium Lauril Sulfat (sabun-detergen). Wilkinson mengatakan bahwa "kebanyakan shampo didasarkan pada kombinasi sabun dan detergen, dari kombinasi tersebut akan menghasilkan modifikasi shampo yang baik (Wilkinson, 1962). Itulah mengapa pada formula A3 peneliti menggunakan kombinasi emulgator sabun dan detergen. Ketiga emulgator tersebut merupakan emulgator anionik. Penggunaan emulgator golongan anionik dikarenakan dapat juga berfungsi sebagai pembusa.
Variasi konsentrasi bahan peningkat viskositas dilakukan berdasarkan pada pernyataan yang dikemukakan oleh Martin yaitu "kemungkinan besar yang diperlukan untuk mendorong terjadinya kestabilan adalah viskositas optimum bukan viskositas yang tinggi" (Martin, 1993). Berdasarkan hal tersebut timbul suatu pemikiran bahwa selain emulgator sebagai bahan penstabil suatu emulsi, ternyata viskositas juga mempunyai peranan dalam menstabilkan emulsi. Olehnya itu peneliti mencoba membuat suatu formulasi shampo dengan memperhatikan dua faktor tersebut yakni viskositas dan emulgator.

Bahan peningkat viskositas yang digunakan dalam penelitian ini adalah karbopol dimana konsentrasinya mulai dari $0,1 \%-0,5$ \%. Karbopol merupakan bahan peningkat viskositas yang paling sering digunakan dalam formulasi shampo dan krim wajah. Karbopol adalah bahan peningkat viskositas fase air, dalam formulasi ini yang merupakan fase luar(fase pendispersi) adalah air, itulah mengapa yang divariasikan bahan peningkat viskositasnya adalah fase air, bukan fase minyaknya. Dimana 
Formulasi Shampo Krim Cair Dari Kombinasi Ekstrak Daun Waru (Dan Sari Buah Jeruk Nipis

perbandingan antara fase minyak dan fase air adalah adalah $\quad 60: 40$.

Selain penggunaan emulgator dan bahan peningkat viskositas juga ditambahkan bahan-bahan lain seperti setil alkohol bekerja pada epidermis dimana berfungsi menjaga kelembaban serta melembutkan kulit. Gliserin berfungsi sebagai humektan yaitu mencegah kekeringan sediaan utamanya dalam wadah. Metil paraben dan propil paraben efektif bila dikombinasikan dengan konsentrasi metil paraben $0,18 \%$ dan propil paraben $0,02 \%$ sebagai bahan pengawet. Alfa tokoferol sebagai antioksidan karena sediaan ini mengandung bahan-bahan yang mudah teroksidasi utamanya bahan yang berupa minyak. Lanolin berfungsi melapisi rambut setelah keramas sehingga rambut tidak kusut dan terasa halus. EDTA (Etilen diamin tetra asetat) berfungsi sebagai pengkhelat.

\section{Evaluasi kestabilan shampo}

dari ekstrak daun waru (Hibiscus tiliaceus L.) dan sari buah jeruk nipis (Citrus aurantifolia Swingle) dilakukan dengan beberapa pengujian antara lain :

\section{Pemeriksaan organoleptis}

Pengujian ini dilakukan untuk mengetahui ada tidaknya perubahan pada warna, bau dan konsistensi dari sediaan sebelum dan sesudah kondisi dipaksakan. Hasil pengamatan yang diperoleh dari sembilan formula shampo cair ekstrak daun waru (Hibiscus tiliaceus L.) dan sari buah jeruk nipis (Citrus aurantifolia Swingle) sebelum dan sesudah penyimpanan tidak memperlihatkan perubahan baik dari segi warna, bau maupun konsistensi sediaan. Sehingga dapat disimpulkan bahwa kesembilan formula stabil.

\section{Pegukuran $\mathrm{pH}$}

Pengukuran $\mathrm{pH}$ dari sediaan shampo harus dilakukan sebelum maupun sesudah kondisi dipaksakan. Ini berkaitan dengan keamanan penggunaan sediaan untuk menghindari terjadinya iritasi kulit bagi pemakainya.

$\mathrm{pH}$ meter adalah media yang digunakan dalam pengukuran $\mathrm{pH}$ sediaan shampo krim cair ekstrak daun waru (Hibiscus tiliaceus L.) dan sari buah jeruk nipis (Citrus aurantifolia Swingle). Adapun hasil yang diperoleh yaitu dari sembilan formula baik sebelum dan sesudah penyimpanan dipercepat dengan kondisi dipaksakan kisaran pHnya yakni 5 . Hal ini sesuai dengan $\mathrm{pH}$ kulit normal manusia yakni berkisar 
Formulasi Shampo Krim Cair Dari Kombinasi Ekstrak Daun Waru (Dan Sari Buah Jeruk Nipis

antara 5-7, sehingaa dapat disimpulkan kesembilan formula stabil.

\section{Pengujian volume kriming}

Kriming adalah pergerakan ke atas dari fase terdispersi. Hal ini biasa disebabkan karena adanya perbedaan jumlah dari kedua fase. Dimana fase yang jumlahnya lebih banyak (fase pendispersi) akan mendesak fase yang lebih sedikit jumlahnya (fase terdispersi), sehingga fase terdispersi ini akan terdorong keluar dari sistem emulsi dan bergerak keatas. Kriming merupakan salah satu gejala ketidakstabilan dari suatu emulsi.

Hasil pengujian menggunakan volume kriming menunjukan bahwa dari sembilan formula shampo krim cair ekstrak daun waru (Hibiscus tiliaceus L.) dan sari buah jeruk nipis (Citrus aurantifolia Swingle) tidak menunjukan adanya kriming. Hal ini disebabkan karena emulgator yang digunakan membentuk lapisan yang rapat disekeliling permukaan tetes minyak yang terdispersi. Sehingga dari pengujian volume kriming dapat disimpulkan bahwa semua formula stabil.

\section{Pengujian tipe emulsi}

Pengujian tipe emulsi menggunakan metode daya hantar listrik. Hasil menunjukan bahwa dari sembilan formula tipe emulsi yang terbentuk adalah m/a (minyak dalam air) baik pada penyimpanan sebelum maupun sesudah kondisi dipaksakan yang ditandai dengan bergeraknya jarum voltmeter. Tipe emulsi yang terbentuk disebabkan karena jumlah fase air lebih banyak daripada fase minyak sehingga yang terbentuk adalah emulsi minyak dalam air. Karena tidak adanya perubahan tipe emulsi pada penyimpanan dipercepat sebelum dan sesudah kondisi dipaksakan, sehingga dapat disimpulkan bahwa kesembilan formula stabil.

\section{Penentuan tetes terdispersi}

Pengujian yang juga dilakukan adalah analisa ukuran tetes terdispersi. Namun, karena keterbatasan alat maka tidak dapat diukur diameter partikelnya, hanya dapat diamati. Berdasarkan hasil pengamatan, dapat dikatakan bahwa tidak terjadi penggabungan tetes terdesipersi dari emulsi shampo krim cair ekstrak daun 
Formulasi Shampo Krim Cair Dari Kombinasi Ekstrak Daun Waru (Dan Sari Buah Jeruk Nipis

waru (Hibiscus tiliaceus L.) dan sari buah jeruk nipis (Citrus aurantifolia Swingle) pada kesembilan formula setelah kondisi dipaksakan. Sehingga dapat disimpulkan bahwa kesembilan formula stabil.

\section{Pengujian homogenitas}

Emulsi yang terbentuk pada shampo krim cair dari ekstrak daun waru (Hibiscus tiliaceus L.) dan sari buah jeruk nipis (Citrus aurantifolia Swingle) menunjukan susunan yang homogen baik sebelum dan sesudah kondisi dipaksakan. Sehingga dapat disimpulkan bahwa kesembilan formula stabil.

7. Pengujian pemisahan fase dengan metode sentrifugasi

Setelah dilakukan pengujian sentrifugasi selama 15 menit dengan kecepatan 2500 rpm pada kesembilan formula tidak menunjukan adanya pemisahan fase baik sebelum maupun sesudah kondisi dipaksakan, sehingga dapat disimpulkan semua formula stabil.

\section{Pengukuran viskositas}

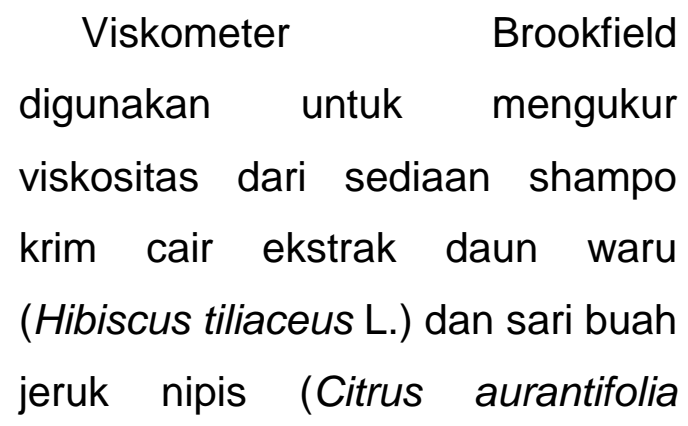

Swingle). Viskositas sediaan diukur menggunakan spindle no.64 dengan kecepatan $50 \mathrm{rpm}$ sebanyak tiga kali replikasi.

Dari data yang diperoleh, dilakukan analisa secara statistik dengan menggunakan metode "Faktorial". Hasil analisis menunjukan bahwa dari kesembilan formula menunjukan pengaruh yang sangat signifikan pada taraf $1 \%$ baik terhadap emulgator, konsentrasi pengental maupun kondisi penyimpanan. Selanjutnya untuk melihat pengaruh perbedaan tersebut dilakukan perhitungan analisis uji lanjutan dengan menggunakan BNJ (Beda Nyata Jujur). Diperoleh hasil yaitu pada perbandingan antar kondisi darii kesembilan formula menunjukan perbedaan yang sangat signifikan $(\alpha=0,01)$ hal ini berarti bahwa kondisi penyimpanan memiliki pengaruh besar terhadap kestabilan shampo krim cair. Kecuali pada formula A2B1 yang menggunakan emulgator natrium lauril sulfat dengan konsentrasi bahan pengental $0,1 \%$ menunjukan hasil yang nonsignifikan $(\alpha=0.05)$ dimana hal ini dapat diartikan bahwa kondisi tidak memiliki 
Formulasi Shampo Krim Cair Dari Kombinasi Ekstrak Daun Waru (Dan Sari Buah Jeruk Nipis

pengaruh besar terhadap kestabilan formula tersebut.

Dari hasil analisis diatas menunjukan bahwa formula A2B1 (emulgator natrium lauril sulfat) dengan konsentrasi bahan pengental $\quad 0,1 \quad \% \quad$ memiliki kestabilan yang optimum dari segi viskositas.

\section{Penentuan tipe aliran}

Tipe aliran suatu emulsi ditentukan berdasarkan rheogram yang dibentuk oleh sediaan. Aliran dari krim biasanya adalah plastis. Aliran plastis adalah aliran yang memiliki nilai yield.

Data dari hasil penelitian dibuat rheogram hubungan antara "Shearing stress" (tekanan geser) dan "Rate of shear " (kecepatan geser), diperoleh sifat aliran non newton yaitu aliran plastis, Rheogram yang diperoleh menunjukan bahwa semua formula stabil.

Rheogram baik kondisi sebelum dan sesudah kondisi dipaksakan formula A3B3 terlihat kurva yang berimipitan. Hal ini menunjukan formula A3B3 yakni formula yang menggunakan emulgator natrium lauril sulfat dengan konsentrasi bahan pengental 0,5\% merupakan formula yang memiliki kestabilan optimum.

Nilai yield adalah nilai yang harus dilampaui oleh suatu sediaan untuk bisa mengalir melewati wadahnya. Nilai yield merupakan parameter yang menentukan kemampuan suatu sediaan untuk mengalir yaitu kemudahannya untuk dituang dalami wadah dan daya sebar sediaan pada saat diaplikasikan. Semakin besar nilai yield maka semakin sulit untuk dituang dan menyebar pada penggunannya. Nilai yield sangat bergantung pada viskositas sehingga bila terjadi perubahan viskositas maka juga akan mempengaruhi nilai yield.

Hasil analisa statistik Faktorial terhadap nilai yield memperlihatkan adanya perbedaan sangat signifikan $(\alpha=0,01)$ baik pada emulgator, konsentrasi pengental dan kondisi. Selanjutnya dilakukan pengujian analisis lanjutan dengan menggunakan BNJ (Beda Nyata Jujur). Dari hasil analisis menunjukan dari kesembilan formula hanya satu formula yang memiliki kestabilan optimum yakni pada formula A3B3 yakni formula yang menggunakan emulgator 
Formulasi Shampo Krim Cair Dari Kombinasi Ekstrak Daun Waru (Dan Sari Buah Jeruk Nipis

natrium lauril sulfat dengan konsentrasi bahan pengental 0,5 $\%$, dimana pada formula ini tidak menunjukan pengaruh yang nyata baik terhadap kondisi penyimpanan, emulgator maupun konsentrasi pengental.

\section{KESIMPULAN}

Kesimpulan yang diperoleh dari hasil penelitian ini yaitu semua formula menghasilkan emulsi yang stabil, tetapi yang memiliki kestabilan paling optimum adalah formula A3B3 yakni formula yang menggunakan emulgator natrium lauril sulfat dengan konsentrasi bahan pengental 0,5\%

\section{DAFTAR PUSTAKA}

Ansel, Howard. 2005. Pengantar Bentuk Sediaan Farmasi. UIPress : Jakarta

Balsam, M.S. 1972. Cosmetics Science and Technology. John Wiley co : New York

Banker, Gilbert.S. 2002. Modern Pharmaceutics Fourth edition, Revised and Expanded. Marcel Dekker Inc : New York

Baumann, Leslie. 2002. Cosmetic Dermatology Principles and Practice. The Mc Graw-Hill Companies : Hongkong

Dalimartha, Setiawan. 2000. Atlas Tumbuhan Obat Indonesia Jilid II. Trubus Agriwidya : Jakarta
Ditjen POM. 1986. Sediaan Galenik. Departemen Kesehatan Republik Indonesia : Jakarta

Ernest W, Flick. 1989. Cosmetic and Toiletry Formulation. Noyes Publication : USA

Gana, dkk. 2007. Jurnal penelitian Uji Efek Minyak Wijen, Ekstrak Daun Waru dan Ekstrak Daun Mangkok terhadap Pertumbuhan dan Kelebatan Rambut pada Tikus Wistar. (online). ITB : Bandung

Hariana, arief. 2004. Tumbuhan Obat dan Khasiatnya Seri I. PT Seri Agri Sehat : Bogor

Gennaro, Alfonso R., 1990. Rhemington: The Science and Practice of Pharmacy $20^{\text {th }}$ edition. Philadelphia College of Pharmacy and Science: Philadelphia

Jellineck, Stephan. 1970. Formulation and Function of Cosmetic : New York

Keithler, W.M. 1997. The Formulation of Cosmetic and Cosmetic Specialties. Drug and Cosmetic Industry : New York

Lachman,L.,Liebermen,H.A.,kanig,J.L. 1986. The Teory and Practice of industrial pharmacy Third Edition. Lea and Febiger : Philladelphia

Martin, W., 1971. Dispending of Medication $7^{\text {th }}$ edition. Marck Publishing Company : USA.

Michael. 1977. A Formulary of cosmetic preparations. Chemical Publishing Company : New York 
Formulasi Shampo Krim Cair Dari Kombinasi Ekstrak Daun Waru (Dan Sari Buah Jeruk Nipis

Parrot, Eugene L. 1971. Pharmaceutical Technology Fundamental. Burgess

Publishing Company: Lowa

Pearce, Evelyn C. 2009. Anatomi dan Fisiologi Untuk Paramedis. PT.Gramedia : Jakarta

Prayetno, Deni. 2008. Emulsi, Shampo, Lotion, Cleansing Cream. (online). (http://dprayetno.wordpress.co m/emulsi-shampo-lotionclensing-cream/) diakses 21 Juni 2008

Rosen, Milton. 1976. Surfactan and interfacial Phenomena. John Wiley and Sons Inc : Toronto

Rowe, Raymond C., Sheskey, Paul., Owen, Sian C. 2009. Handbook of Pharmaceutical Excipients Ebook. Pharmaceutical Press and American Pharmacists Association 2006 :USA
Steenis, C.G.G.J. Van. 2006. Flora. PT PERCA : Jakarta

Sylvia A, Price. 2006. Patofisiologi Edisi VI. Penerbit buku kedokteran EGC : Jakarta

Syukri, dkk. 2008. Formulasi Emulsi Ganda Virgin Coconut Oil (VCO) Dengan Emulgator Span 80 dan Tween 60. (online). (Jurnal Ilmiah Farmasi Vol.5 No.1 Tahun 2008/Formulasi Emulsi Ganda Virgin Coconut oil (VCO) Dengan Emulgator Span 80 dan Tween 60)

Tjitrosoepomo, G. 1998. Taksonomi Tumbuhan Obat-Obatan. UGM Press : Yogyakarta

Wilkinson, J.B. 1962. Modern Cosmeticology ; The principle and practice of modern cosmetics volume one. Chemical publishing Co : New York 